\title{
Capacitance spectroscopy of InAs self-assembled quantum dots
}

\author{
P. M. Martin*, A. E. Belyaev ${ }^{* *}$, L. Eaves, P. C. Main, F. W. Sheard, T. Ihn ${ }^{* * *}$, M. Henini \\ Department of Physics, University of Nottingham, Nottingham, NG7 2RD, UK \\ *Present address: Dept. of Electronic \& Electrical Engineering, University of Sheffield, Sheffield, S1 3JD, UK \\ **On leave from Institute of Semiconductor Physics, NASU, Kyiv, 252028, Ukraine \\ ***Present address: Solid State Physics Lab., ETH Hoenggerberg, CH-8093 Zurich, Switzerland
}

\begin{abstract}
Capacitance spectroscopy is used to study electronic properties of self-assembled InAs quantum dots. The capacitance-voltage, $\mathrm{C}(\mathrm{V})$, measurements in combination with the magneto-capacitance, $\mathrm{C}(\mathrm{B})$, results make it possible to investigate the electrostatic profile of a series of single-barrier $n-i-n$ $\mathrm{GaAs} / \mathrm{AlAs} / \mathrm{GaAs}$ heterostructures incorporating a layer of self-assembled InAs quantum dots in the AlAs barrier. We find that the negative charge associated with electron filling of the dots is closely compensated by a positive charge in the AlAs barrier, which we ascribe to ionised defects or impurities, possibly in association with the quantum dots. It is shown the compensation degree considerably depends on the growth conditions.
\end{abstract}

Keywords: MBE growth, InAs quantum dots, capacitance spectroscopy.

Paper received 16.09.98; revised manuscript received 19.10.98; accepted for publication 28.10.98.

\section{Introduction}

A semiconductor quantum dot (QD) is the ultimate quantum-confined system. Its unique electronic properties rely on the delta-function-like energy dependence of the density of states due to the quantum confinement of carriers in all three dimensions [1]. At the same time, to exploit these promising properties in a new generation of devices, the lateral dimensions of the structures have to be smaller than the principal characteristic length - the de Broglie wavelength of electrons. The second basic requirement is uniformity in the size and shape of a large ensemble of QDs densely packed in the active volume of the device. Among the existing techniques of QD fabrication, direct heteroepitaxial growth of highly strained structures by MBE and MOVPE (self-organized Stranski-Krastanov heteroepitaxial growth [2]) has gained great interest because of the possibility to obtain structures with a desired shape and, most important, narrow size distribution [3]. The success achieved by this technique in recent years attracts much interest to the optical and electronic properties of QD arrays. A lot of works were made to characterise the energy and density of electronic states, electrical transport, and recombination processes in the QDs. This has been done using photoluminescence [4-6] and electrical techniques $[7,8]$. Another method is using capacitance [9-11] or magneto-capacitance spectroscopy [12, 13]. Capacitance studies are very promising for investigation of QDcontained structures and QD electronic states because of their high sensitivity to the charge transferred through the struc- ture. Note that most of capacitance measurements were made on Schottky barrier structures. Such structures have definite advantages, because by applying voltage we can scan through the energy spectrum of QDs. However, the band bending initially present in these structures does not allow observing the effects associated with piezoelectric fields and interface states. Besides, practically all experiments have been carried out on QDs embedded in GaAs matrix.

In this paper we investigate the capacitance-voltage, $\mathrm{C}(\mathrm{V})$, and magneto-capacitance, $\mathrm{C}(\mathrm{B})$, characteristics of a series of single-barrier n-i-n GaAs/AlAs/GaAs heterostructures incorporating a layer of self-assembled InAs QDs in the AlAs barrier. The thicknesses of the layers of AlAs deposited before and after the InAs QD growth are varied. The $C(V)$ and $C(B)$ results are compared with those for a reference sample having no InAs and a sample in which InAs thickness is such that a continuous wetting layer (WL) of InAs is grown. The shape of the $\mathrm{C}(\mathrm{V})$ curve can be understood in terms of a simple device model discussed in this paper. The net charge density in the QD-containing barrier is determined from analysis of the $\mathrm{C}(\mathrm{V})$ results in combination with the $\mathrm{C}(\mathrm{B})$ results, and is confirmed using results from the reference sample. We find the net charge in all QD samples to be close to zero or positive at zero bias applied. The effect of this charge is to radically alter the picture of the band bending in the devices in comparison to the model derived from consideration of only the QD electronic states [13]. 


\section{P. M. Martin et al.: Capacitance spectroscopy of InAs self-assembled quantum dots}

\section{Experimental procedure}

The samples presented in this study were grown on a (100) $n^{+}$GaAs substrate using MBE and all consist of n-type GaAs devices with an AlAs tunnel barrier region surrounded by $100 \mathrm{~nm}$ not intentionally doped spacers to minimise the effect of dopant diffusion into the central barrier region. These spacers are then enclosed by $100 \mathrm{~nm}$ of n-type lightly doped $\left(10^{16} \mathrm{~cm}^{-3}\right)$ GaAs layer, followed by $100 \mathrm{~nm}$ doped to $10^{17} \mathrm{~cm}^{-3}$, and then a heavily doped $\left(10^{18} \mathrm{~cm}^{-3}\right)$ contact layer. The reference sample consists of a $10 \mathrm{~nm}$ AlAs single barrier, while the WL sample consists of an AlAs double barrier structure enclosing 1.4 ML of InAs. The QD samples consist of an InAs QD layer enclosed in AlAs layers grown previously and subsequently to the QD growth. The QDs are produced by deposition of $1.8 \mathrm{ML}$ of InAs at a growth temperature of $520^{\circ} \mathrm{C}$. Layer parameters for the samples studied in this work are shown in Table 1. The band diagram of the samples at zero voltage and under bias is schematically shown in fig. 1. Electrical contacts were formed on the doped GaAs layer by AuGe alloying, and devices were fabricated into mesas of $200 \mu \mathrm{m}$ diameter. In this paper, the convention of negative substrate for forward bias is used. All capacitance measurements were made with a HP 4275A MultiFrequency LCR Meter, in a variable temperature cryostat. The frequency range of the $\mathrm{C}(\mathrm{V})$ analyser was from $10 \mathrm{kHz}$ to $10 \mathrm{MHz}$. No discernible difference in the functional form of the $\mathrm{C}(\mathrm{V})$ curve was found over this range of frequencies.

\section{Experimental results and discussion}

Fig. 2 shows the capacitance-voltage curves of the samples listed in Table 1. The capacitance values for the WL and QD samples have each been displaced by $4 \mathrm{pF}$ for clarity. The capacitance data were obtained using the modulation amplitude of $2 \mathrm{mV}$ at $1 \mathrm{MHz}$ with an LCR meter set in parallel RC measurement mode. This measurement treats the sample as if it were a parallel combination of impedance, $R$, and single capacitance, C. Actually, our devices have a more complex equivalent circuit shown in fig. 1(c). The heavily

Table 1. The layer composition of InAs QD samples and the reference sample.

\begin{tabular}{cccc}
\hline Sample & $\begin{array}{c}\text { Underlayer, } \\
\mathbf{n m}\end{array}$ & $\begin{array}{c}\text { InAs layer, } \\
\mathbf{M L}\end{array}$ & $\begin{array}{c}\text { Overlayer, } \\
\mathbf{n m}\end{array}$ \\
\hline $\mathrm{A}$ & 5.1 & 1.8 & 5.1 \\
$\mathrm{~B}$ & 3.4 & 1.8 & 6.4 \\
$\mathrm{C}$ & 5.1 & 1.8 & 7.2 \\
$\mathrm{D}$ & 5.1 & 1.8 & 3.8 \\
WL & 5.1 & 1.4 & 5.1 \\
Control & $\begin{array}{c}10 \text { nm AlAs } \\
\text { single barrier }\end{array}$ & no QDs & \\
\hline
\end{tabular}

a)

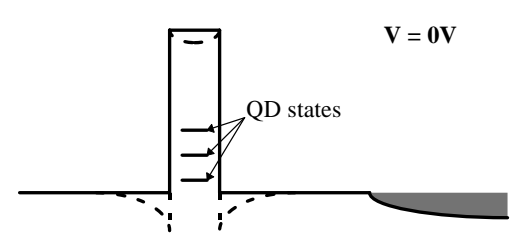

b)
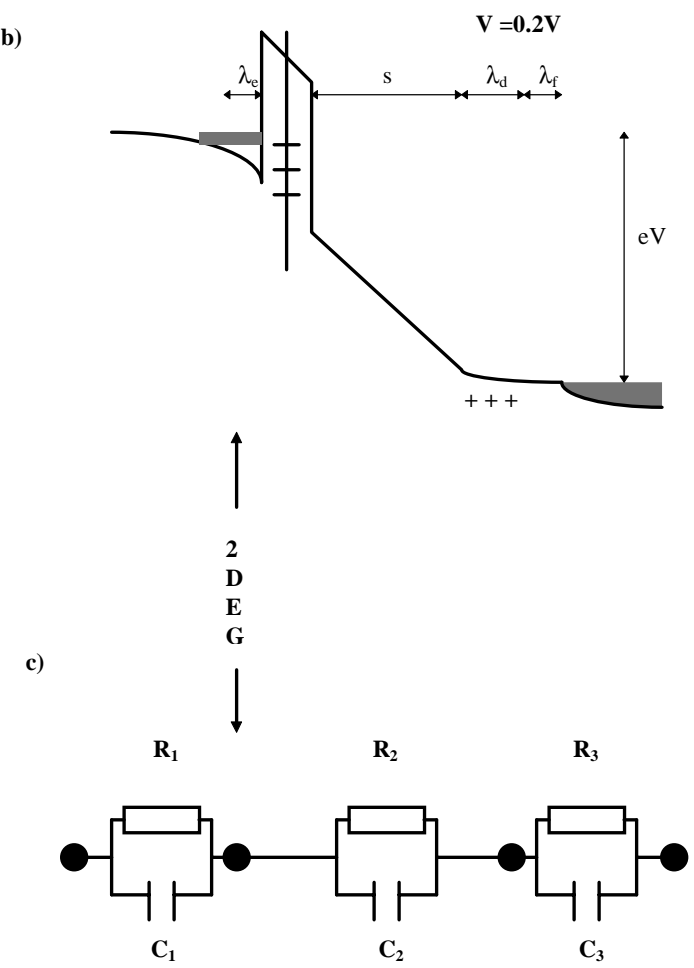

Fig. 1. Schematic band diagrams of the device at zero bias (a) and $0.2 \mathrm{~V}$ (b), and the equivalent electric circuit of the device (c).

doped regions of the device effectively act as the outer conducting plates of a capacitor. In addition, under a sufficient bias a two-dimensional electron gas (2DEG) forms in the

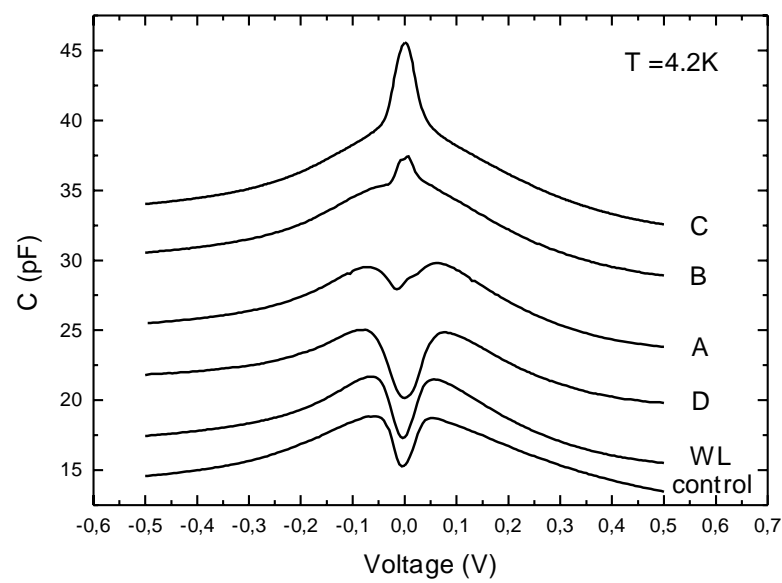

Fig. 2. Capacitance-voltage curves for various devices measured at $4 \mathrm{~K}$ and zero magnetic field. Top five curves are displaced vertically by values of $\Delta \mathrm{C}=4 \mathrm{pF}$ each for clarity. 


\section{P. M. Martin et al.: Capacitance spectroscopy of InAs self-assembled quantum dots}

accumulation layer adjacent to the left-hand barrier, as shown in fig. 1(b). It acts as a third region of mobile electron charge. The parallel impedance combination $\mathrm{C}_{1}$ and $\mathrm{R}_{1}$ represents the slab of GaAs between the heavily doped layer and the $2 \mathrm{DEG}, \mathrm{C}_{2}$ and $\mathrm{R}_{2}$ represent the barrier and depletion region between the $2 \mathrm{DEG}$ and the contact, while $\mathrm{C}_{3}$ and $\mathrm{R}_{3}$ account for the effect of the impedance of the undepleted lightly doped region.

It can be seen that there is no clear distinction between QD and non-QD samples apparent from the $\mathrm{C}(\mathrm{V})$ characteristics. All C(V) curves have a common shape for biases above $\sim 200 \mathrm{mV}$, characterised by a declining capacitance. This is what should be expected, as the capacitance of all samples is simply dominated by that of the depleted contact region. Most variance seen in the samples is in the shape of $\mathrm{C}(\mathrm{V})$ around zero voltage. There are four samples that exhibit a pronounced dip in $\mathrm{C}(\mathrm{V})$, while two of QD samples show a pronounced peak at zero bias. To understand the origin of the form of the $\mathrm{C}(\mathrm{V})$ dependences, we will follow the arguments described below.

If at zero bias there is no net charge in the barrier (or there is a small negative charge), then at low bias voltages we have accumulation on the left-hand side and depletion on the right-hand side. In this case, resistances $R_{1}$ and $R_{3}$ more or less short circuit $C_{1}$ and $C_{3}$. Also, $R_{2} \cong \infty$, since the AlAs barrier is thick and high. So, we are concerned mainly with the behaviour of $\mathrm{C}_{2}$. The areal capacitance $\mathrm{C}_{2}$ is equal to $\varepsilon_{\mathrm{r}} \varepsilon_{0} / \mathrm{d}$. Here $\mathrm{d}=\lambda_{\mathrm{e}}+\mathrm{b}+\mathrm{s}+\lambda_{\mathrm{d}}$, where $\lambda_{\mathrm{e}}$ is the quantum stand-off distance of the electrons in the 2 DEG, $s$ is the undoped spacer layer thickness, $\lambda_{\mathrm{d}}$ is the depletion layer width and $\lambda_{f}$ is the width of the lightly doped contact layer - see fig. 1(b). Thus, $\mathrm{C}_{2}$ will strongly depend on the variation of $\lambda_{\mathrm{e}}$ and $\lambda_{\mathrm{d}}$. The Fang-Howard theory [14] gives $\lambda_{\mathrm{e}} \sim \mathrm{n}_{\mathrm{s}}^{-1 / 3}$ and $\lambda_{\mathrm{d}} \sim \mathrm{n}_{\mathrm{s}}$, where $\mathrm{n}_{\mathrm{s}} \mathrm{e}$ is the areal charge in the lefthand side 2DEG. So, at a low $n_{s} 1 / C_{2}$ is proportional to $n_{\mathrm{s}}^{-1 / 3}$, but at a high $\mathrm{n}_{\mathrm{s}} 1 / \mathrm{C}_{2}$ gradually increases with $\mathrm{n}_{\mathrm{s}}$. This shows qualitatively that there is a maximum in $\mathrm{C}_{2}$, and consequently in the measured capacitance, at a finite $n_{s}$ (nonzero voltage), and minimum at zero voltage. The reference sample has a clear minimum in capacitance at $0 \mathrm{~V}$, a feature that is shared by the wetting layer sample, and QD samples $\mathrm{A}$ and $\mathrm{D}$. Therefore, the similarity in the capacitance values at low bias leads to the conclusion that samples A and D and the reference sample as well as the WL sample are very similar electrostatically, and that the QD-containing barrier in samples A and D is almost electrically neutral.

If we assume that the samples have a small positive charge in the barrier (associated with QDs), then at zero bias both contacts are accumulated. Under these conditions, the middle capacitance $\mathrm{C}_{2}$ is given by the expression: $1 / \mathrm{C}_{2} \sim \lambda_{\mathrm{e} 1}+\mathrm{b}+\lambda_{\mathrm{e} 2}$, where $\lambda_{\mathrm{e} 1}$ and $\lambda_{\mathrm{e} 2}$ are the quantum standoff distances of electrons in the $2 \mathrm{DEG}$ formed in front and at rear of the barrier. Both $\lambda_{\mathrm{e} 1}$ and $\lambda_{\mathrm{e} 2}$ will be determined by sheet density of the 2DEG, i.e. $\lambda_{\mathrm{e} 1} \sim \mathrm{n}_{\mathrm{s} 1}{ }^{-1 / 3}$ and $\lambda_{\mathrm{e} 2} \sim \mathrm{n}_{\mathrm{s} 2}{ }^{-1 / 3}$, and $\mathrm{n}_{\mathrm{s} 1}+\mathrm{n}_{\mathrm{s} 2}=\mathrm{N}_{0}$, where $\mathrm{N}_{0}$ is the net positive charge density concentrated in the barrier. A simple algebra shows that in the case $\mathrm{n}_{\mathrm{s} 1}=\mathrm{n}_{\mathrm{s} 2}$ the capacitance $\mathrm{C}_{2}$ has maximum at zero bias. The behaviour of $\mathrm{C}(\mathrm{V})$ characteristics around zero voltage for samples $\mathrm{B}$ and $\mathrm{C}$ is consistent with this interpreta- tion, thus confirming the presence of a net positive charge in the QD-containing barrier.

In order to probe the structures further, magneto-capacitance measurements were performed at $4 \mathrm{~K}$. These included sweeping the magnetic field $\mathrm{B}$, applied in parallel to the growth direction, up to $\sim 10 \mathrm{~T}$ for a given bias voltage. This results in the well-known Shubnikov-de Haas-like magnetooscillations of the capacitance with a periodicity in 1/B, due to the Landau levels in the accumulation layer passing through the Fermi energy [15]. The charge modulation arising in this case affects the distribution of the electrical potential and screening length, and hence modulates the capacitance of the device. The frequency of the oscillations of the fundamental field, $\mathrm{B}_{\mathrm{f}}=[\Delta(1 / \mathrm{B})]^{-1}$, is thus related to the Fermi energy $\mathrm{E}_{\mathrm{F}}$ by $\mathrm{B}_{\mathrm{f}}=2 \pi \mathrm{m} * \mathrm{E}_{\mathrm{F}} / \mathrm{eh}$, where $\mathrm{m} *$ and $\mathrm{h}$ are the effective mass and the Plank constant, respectively. The $\mathrm{B}_{\mathrm{f}}$ therefore measures the electronic sheet density of $2 \mathrm{DEG}$ in the accumulation layer $n_{s}=2 \mathrm{eB}_{\mathrm{f}} / \mathrm{h}$. Typical traces of $\mathrm{C}(\mathrm{B})$ for the sample $A$ are shown in fig. 3. The values of $B_{f}$ extracted from the $\mathrm{C}(\mathrm{B})$ traces are shown for all the QD samples in fig. 4.

First of all, the magneto-oscillation series in $\mathrm{C}(\mathrm{B})$ are of interest because they prove the existence of a thermalised 2DEG and allow the electric field $F$ across the barrier region of the structure to be measured directly: $\mathrm{F}=\mathrm{n}_{\mathrm{s}} \mathrm{e} / \varepsilon_{\mathrm{r}} \varepsilon_{0}$. In a simple single-barrier structure, such as the reference sample, the charge density in the electron accumulation layer can be calculated from the applied voltage given the doping
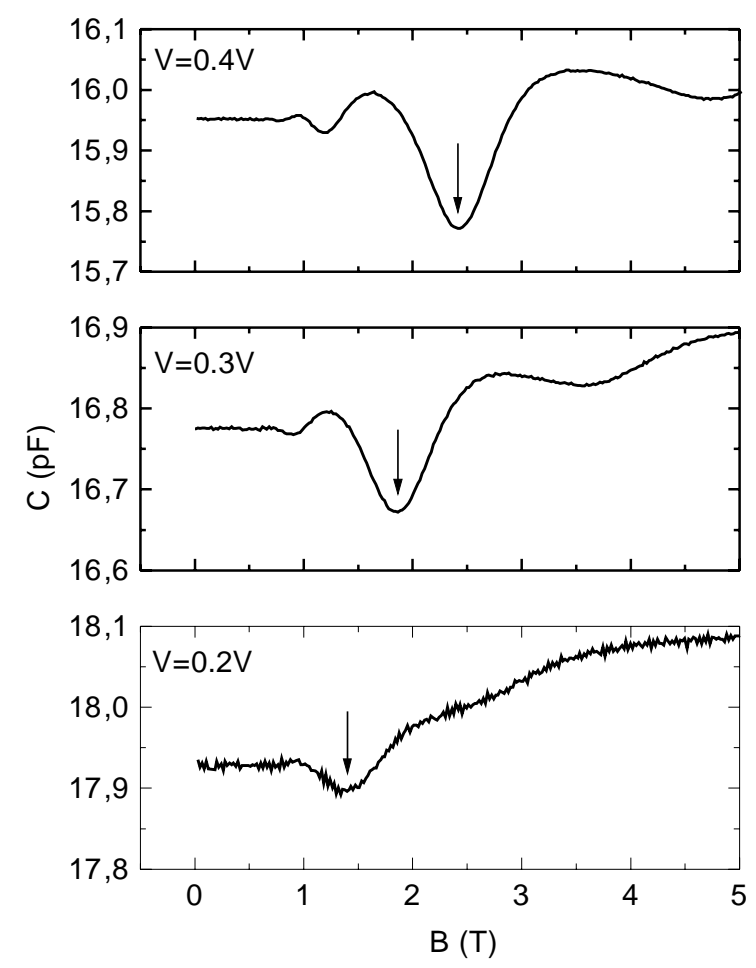

Fig. 3. Magnetocapacitance oscillations measured at $T=4 \mathrm{~K}$ and different bias voltages applied to sample A. 


\section{P. M. Martin et al.: Capacitance spectroscopy of InAs self-assembled quantum dots}

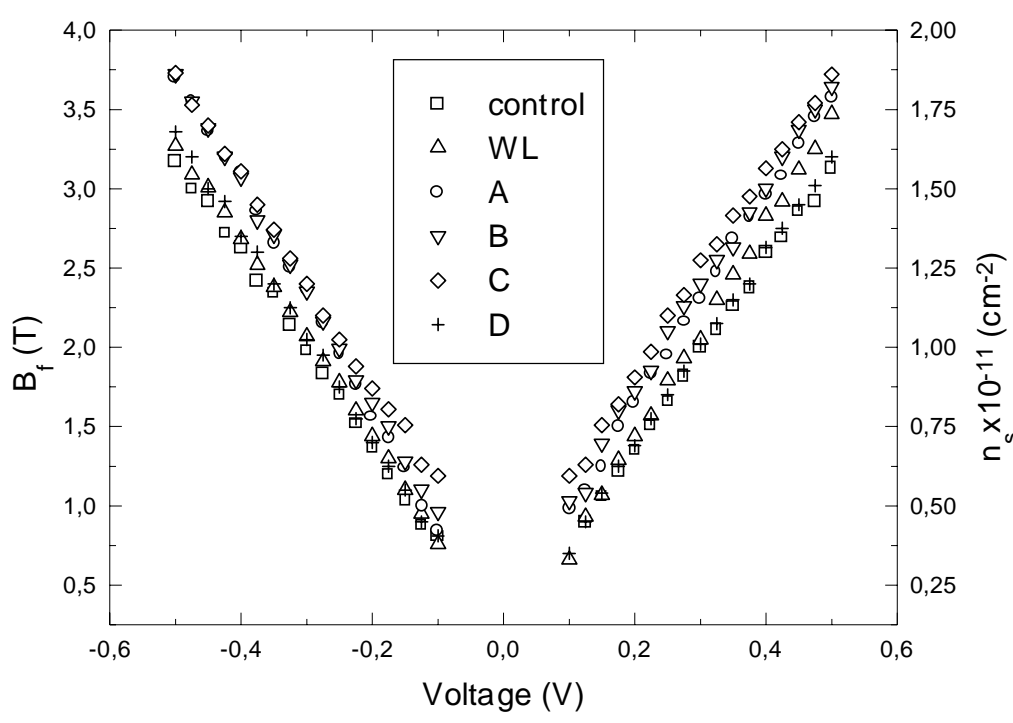

Fig. 4. Fundamental field values, $B_{f}$, (left axis) and charge sheet density, $\mathrm{n}_{\mathrm{s}}$, (right axis) plotted as a function of the applied voltage. profile in the depletion region. This is essentially a result of being able to equate the charge densities in the accumulated and depleted regions. In a structure where there is potentially an additional charge density with an unknown magnitude and bias dependence, such as QD structures, this is not strictly possible because an additional degree of freedom has been introduced, i. e. F can have a contribution from QDs. In this case, the direct measurement of the electronic charge density in the accumulation layer can be used to calculate the unknown charge density at a given bias, in exactly the same manner as described for the single barrier. Simply put, the addition of a degree of freedom requires another one to be ascertained.

The dependencies of $\mathrm{B}_{\mathrm{f}}$ on the applied voltage shown in fig. 4 for all samples are very close to linear ones over the entire voltage range and look very similar, though they appear to be offset to form a family. The curves for samples B and $\mathrm{C}$ have the largest offset in the set and extrapolate to a significant positive value at $0 \mathrm{~V}$. This offset points to a positive net charge in the barrier.

Explanation of the $\mathrm{C}(\mathrm{V})$ and $\mathrm{C}(\mathrm{B})$ results is that a net positive charge exists in the single barrier, at least equal in magnitude to the electronic charge density in the QD layer. The positive charge attracts electrons to the accumulation layers adjacent to the barrier and thus induces the deviations from the capacitance of the reference sample, exhibited most clearly by samples $\mathrm{C}$ and $\mathrm{D}$. The electrons accumulated in the collector under a finite bias will rapidly deplete, and the differential capacitance will return to values very similar to the reference sample, as is seen.

Although the simple model of equivalent circuit used by us can reproduce the general features of the $\mathrm{C}(\mathrm{V})$ and $\mathrm{C}(\mathrm{B})$ curves, the model is insufficiently realistic to predict the results quantitatively, and hence cannot be used for accurate calculations of any charge densities in the QDs.

Instead, the difference in the $\mathrm{C}(\mathrm{V})$ and $\mathrm{C}(\mathrm{B})$ types of measurement can be exploited. The $\mathrm{C}(\mathrm{V})$ trace in principle can be integrated to give the total transferred charge as function of voltage, though this requires the effective area to be given very accurately. The $\mathrm{B}_{\mathrm{f}}$ values from the $\mathrm{C}(\mathrm{B})$ traces

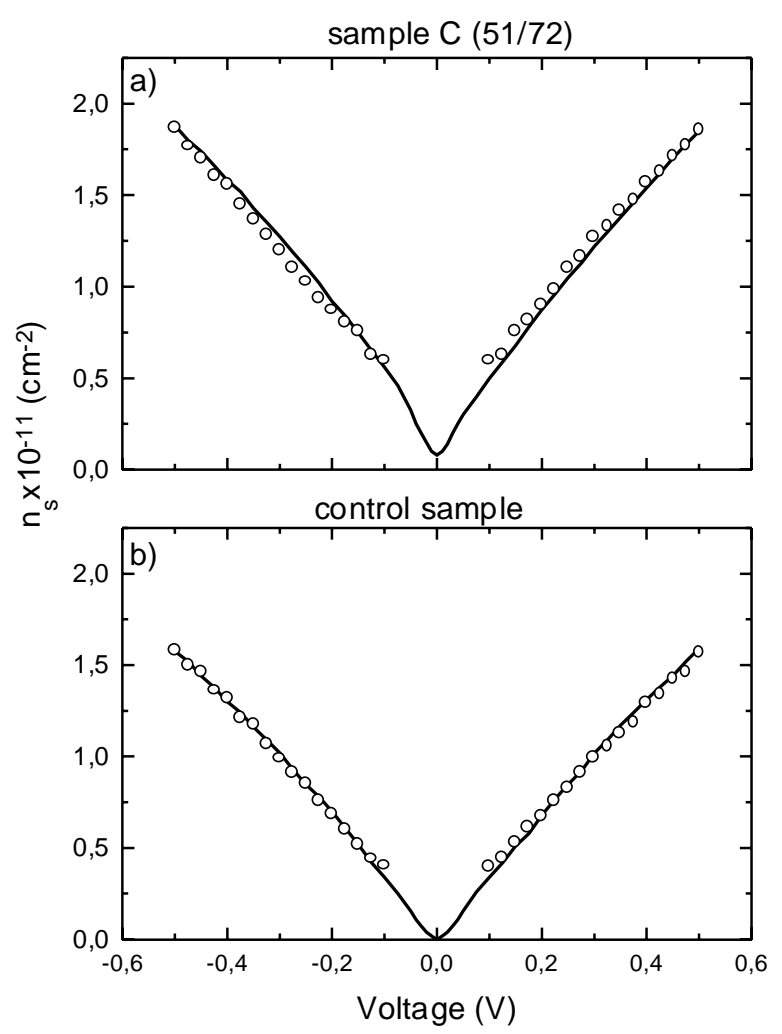

Fig. 5. Integrated $C(V)$ curves (solid lines) and the $n_{s}$ values taken from C(B) traces (circles). Upper - sample C, lower - reference sample. 


\section{P. M. Martin et al.: Capacitance spectroscopy of InAs self-assembled quantum dots}

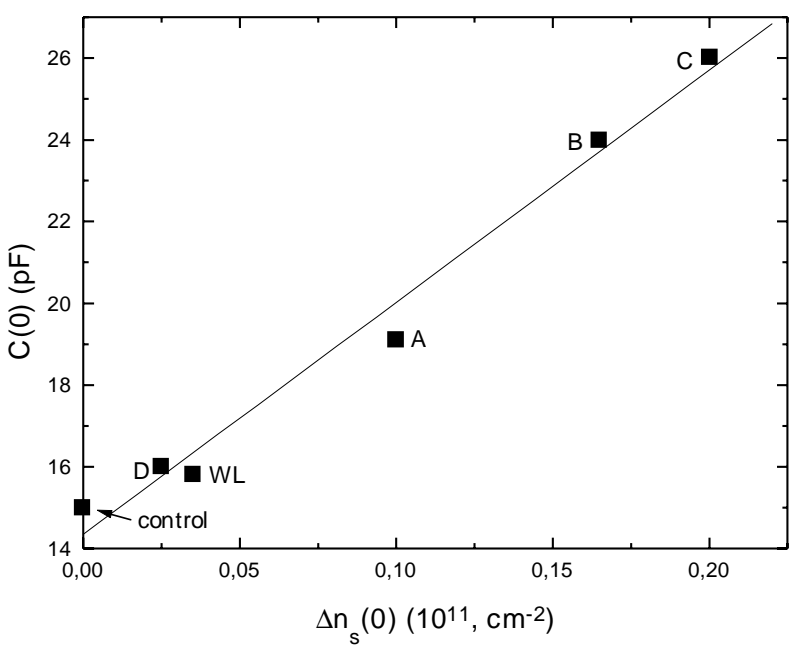

Fig. 6. The values of capacitance at zero voltage versus $\Delta n_{\mathrm{s}}$. Solid line presents the least-squares fit.

yield directly the charge sheet density, $\mathrm{n}_{\mathrm{s}}$, in a particular region, the 2DEG. Fig. 5(a) shows the sheet density calculated using the $\mathrm{B}_{\mathrm{f}}$ data and integrated $\mathrm{C}(\mathrm{V})$ (scaled to give $\mathrm{n}_{\mathrm{s}}$ ) data for the reference sample. The agreement is excellent, given only the mesa radius has been adjusted (within several percents) to bring the curves into agreement. It should be noted that the effect of processing inaccuracies, leading to different device sizes than expected, and stray capacitance will both be subsumed in this single correction. The variation in the device capacitance is sufficiently small, so that a small series stray capacitance will only lead to an approximately constant reduction in the measured value, and thus it mimics the change in the device area. However, the main point to be noted is that the curves are in agreement for all bias values. Fig. 5(b) shows a similar graph for the integrated $\mathrm{C}(\mathrm{V})$ and $\mathrm{n}_{\mathrm{s}}$ values for sample $\mathrm{C}$. In this case, the mesa area and a $0 \mathrm{~V}$ offset (vertical shift of the curve on the whole) added to the integrated $\mathrm{C}(\mathrm{V})$ are used to bring the curves to a fit. The offset used corresponds to a net charge density in the barrier of $1.5 \cdot 10^{10} \mathrm{~cm}^{-2}$. The fit is again excellent over the entire bias range. Note that the $\Delta \mathrm{n}_{\mathrm{s}}$ value obtained is similar to the value one could obtain from inspection of fig. 4. Effectively, the alignment of the curves over the entire bias range allows making a deduction about the behaviour at $0 \mathrm{~V}$. As the $\mathrm{C}(\mathrm{V})$ around $0 \mathrm{~V}$ and the $\mathrm{n}_{\mathrm{s}}$ (or $\mathrm{B}_{\mathrm{f}}$ ) series are close to one another, there appears to be a finite density in the accumulation layers at $0 \mathrm{~V}$.

The same procedure has been performed for all QD samples, and the results are shown in fig. 6 , where the extracted $\Delta \mathrm{n}_{\mathrm{s}}$ values are plotted versus $\mathrm{C}(0)$. Extrapolating the points linearly to zero, $\Delta \mathrm{n}_{\mathrm{s}}$ value, which effectively assumes the electrical neutrality in the barrier of the reference sample, gives the capacitance value very close to that of the reference sample. The result confirms our explanation of the zerofield $\mathrm{C}(\mathrm{V})$ at low temperatures.

\section{Summary}

In conclusion, we investigate the $\mathrm{C}(\mathrm{V})$ and $\mathrm{C}(\mathrm{B})$ characteristics of a series of single-barrier $n-i-n$ GaAs/AlAs/GaAs heterostructures incorporating a layer of self-assembled InAs quantum dots in the AlAs barrier. Some of the samples show minima and some maxima in the zero-field $\mathrm{C}(\mathrm{V})$ at low temperatures. This provides information about the degree of accumulation in the GaAs layers adjacent to the barrier at zero bias. We have shown that the reference sample exhibits the same behaviour as the WL sample, implying electrical neutrality in the barrier of these samples. The QD-containing samples are seen to have a slight excess of positive charge, leading to electron accumulation at zero bias. This positive charge in the AlAs barrier, which we ascribe to ionised defects or impurities, possibly in association with the quantum dots, compensates the negative charge associated with electron filling of the dots, and the compensation degree considerably depends on the growth conditions, in particular on the overlayer thickness. There are two interesting consequences of this arrangement. The first is that there are electrons brought into close contact with the QDs at zero bias applied. The coupling of the electrons to the QDs may be enhanced by this at low biases, and may even lead to interesting zero-bias tunneling effects. Another consequence is that positive charge in the QD-containing barrier radically alters the picture of the band bending in the devices in comparison to the model taking into account only charging of the QD states with electrons.

\section{Acknowledgements}

This work is supported by EPSRC (U.K.). A.E.Belyaev and L.Eaves acknowledge the financial support of the Royal Society and EPSRC, respectively. A.E.B. was partly supported by STCU under Project No.464.

\section{References}

1. D. V. Averin, K. K. Likharev. In: Mesoscopic Phenomena in Solids, Edited by B. L. Altshuler, P. A. Lee, R. A. Webb, Elsevier, Amsterdam, 1991.

2. I. N. Stranski, L. Krastanow. Akad. Wiss. Lit. Mainz Math.-Natur K1. 11b, 146, 797 (1939).

3. R. Notzel. Semicond. Sci. Technol., 11, 1365 (1996).

4. S. Fafard, D. Leonard, J. L. Merz, P. M. Petroff. Appl. Phys. Lett., 65, 1388 (1994).

5. J. Y. Marzin, J. M. Gerard, A. Izrael, D. Barrier, G. Bastard. Phys. Rev. Lett., 73, 716 (1994).

6. M. Grundman, N. Ledentsov, O. Stier, D. Bimberg, V. M. Ustinov, P. S. Kop'ev, Zh. I. Alferov. Appl. Phys. Lett., 68, 979 (1996).

7. M. Narihiro, G. Yusa, Y. Nakamura, T. Noda, H. Sakaki. Appl. Phys. Lett., 70, 105 (1997)

8. I. E. Itskevich, T. Ihn, A. Thornton, M. Henini, H. A. Carmona, L. Eaves, P. C. Main, D. K. Maude, J. C. Portal. Jpn. Journ. Appl. Phys., 36, 4073 (1997).

9. R. C. Ashoori, H. L. Stormer, J. S. Weiner, L. N. Pfeiffer, S. J. Pearton, K. W. Baldwin, K. W. West. Phys. Rev. Lett., 68, 3088 (1992).

10. H. Drexler, D. Leonard, W. Hansen, J. P. Kotthaus, P. M. Petroff. Phys. Rev. Lett., 73, 2252 (1994). 


\section{P. M. Martin et al.: Capacitance spectroscopy of InAs self-assembled quantum dots}

11. G. Medeiros-Ribeiro, D Leonard, P. M. Petroff. Appl. Phys. Lett., 66, 1767 (1995).

12. M. Fricke, A. Lorke, J. P. Kotthaus, G. Medeiros-Ribeiro, P. M. Petroff. Europhys. Lett., 36, 197 (1996).

13. B. T. Miller, W. Hansen, S. Manus, R. J. Luyken, A. Lorke, J. P. Kotthaus, S. Huant, G. Medeiros-Ribeiro, P. M. Petroff. Phys. Rev. B, 56, 6764 (1997).
14. I. E. Itskevich, T. Ihn, A. Thornton, M. Henini, T. J. Foster, P. Moriarty, A. Nogaret, P. H. Beton, L. Eaves, P. C. Main. Phys. Rev. B, 54, 16401 (1996).

15. F. F. Fang, W. E. Howard. Phys. Rev. Lett., 16, 797 (1966).

16. H. L. Leadbeater, E. S. Alves, F. W. Sheard, L. Eaves, M. Henini, O. H. Hughes, G. A. Toombs. J. Phys.: Condens. Matter, 1, 10605 (1989).

\section{ЕМНІСНА СПЕКТРОСКОПІЯ InAs САМО-ОРГАНІЗОВАНИХ КВАНТОВИХ ТОЧОК}

П. М. Мартін

Шеффілдський Університет, Великобританія

О. Е. Беляев

Інститут фізики напівпровідників НАН Украӥни

Л. Івз, П. К. Мейн, Ф. В. Шірд, М. Хеніні

Ноттінгемський Університет, Великобританія

T. IH

Лабораторія фізики твердого тіла, Швейцарія

Смнісна спектроскопія використується для дослідження електронних властивостей само-організованих InAs квантових точок. Вимірювання вольт-фарадних характеристик, $\mathrm{C}(\mathrm{V})$, одночасно 3 даними по магнето-емності, С(В), дозволяють досліджувати електростатичний профіль однобар'єрних p-i-n GaAs/AlAs/GaAs гетероструктур, які містять в AlAs бар'єрі шар самоорганізованих InAs квантових точок. Ми визначили, що негативний заряд, пов'язаний з заповненням квантових точок електронами, майже повністю компенсується позитивним зарядом в AlAs бар'єрі, що, на нашу думку, пов’язано з іонізованими дефектами чи домішками, які обумовлені квантовими точками. Показано, що міра компенсації суттєво залежить від ростових умов.

\section{ЕМКОСТНАЯ СПЕКТРОСКОПИЯ InAs САМО-ОРГАНИЗОВАННЫХ КВАНТОВЫХ ТОЧЕК}

П. М. Мартин

Шеффилдский Университет, Великобритания

А. Е. Беляев

Институт физики полупроводников НАН Украины

Л. Ивз, П. К. Мэйн, Ф. В. Ширд, М. Хенини

Ноттингемский Университет, Великобритания

T. Ин

Лаборатория физики твердого тела, Нвейцария

Емкостная спектроскопия используется для исследования электронных свойств само-организованных InAs квантовых точек. Измерение вольт-фарадных характеристик, C(V), совместно с данными по магнето-емкости, С(B), позволяют исследовать электростатический профиль однобарьерных p-i-n GaAs/AlAs/GaAs гетероструктур, содержащих в AlAs барьере слой самоорганизованных InAs квантовых точек. Мы установили, что отрицательный заряд, связанный с заполнением квантовых точек электронами, почти полностью компенсируется положительным зарядом в AlАs барьере, который, по нашему мнению, связан с ионизованными дефектами или примесями, обусловленными квантовыми точками. Показано, что степень компенсации существенно зависит от ростовых условий. 